\title{
Water Supply and Demand for Different Sectors in Bhavani Basin
}

\author{
A. Malaisamy \\ Agricultural Economics, Tamil Nadu Agricultural University, Tamil Nadu, India \\ Corresponding author: malaisamyecon@gmail.com (ORCID ID: 0000-0001-8822-6714)
}

Paper No. 898

Received: 07-04-2021

Revised: $27-05-2021$

Accepted: 09-06-2021

\begin{abstract}
The irrigated crops Demand based on water requirement is 2.12 m.ha.m (44.72 percent). This Demandsupply gap is 0.48 m.ha.m. (Palanisami 2013). India food grain need is 450 MT by the year 2050. The irrigation sector consumes the majority of water, and more attention is required in this sector. Almost all the utilizable potential will have to be harnessed to meet the demand for agriculture, industry, energy generation, and domestic consumption. The National Water Policy (2002) gives overriding priority to drinking water over other uses. Taking an average of 200 liters per capita per day (liter per consumer demand), the urban demand for water for the population of 1000 million (2012 estimate) would be 73.17 BCM, of which consumptive use should only be $14.63 \mathrm{BCM}(20 \%)$. A quantity of $14.63 \mathrm{BCM}$ is too tiny compared to the total potential to pose any supply problem. Due to improper wastewater management, the water Demand projected as $60 \mathrm{BCM}$ compared to the actual demand 14.63 BCM. The drinking water Demand is $10 \mathrm{BCM}$ at the present level of 40 liter per consumer and it would be 29 BCM by $2050 \mathrm{~d}$ (Ministry of Water Resources, 2018 estimate).
\end{abstract}

\section{HIGHLIGHTS \\ (0 Domestic water demand shall be 820 Million by 2050 . \\ ( Industrial uses of water are likely to be about 25 percent in the year 2025 AD. \\ (0 The annual food grain requirement works out to be 450 MT by the year 2050 .}

Keywords: Water demand and supply, agricultural water sector, domestic sector, industries sector

\section{Water Demand}

Seventeen river basins are available in Tamil Nadu, with a geographical area of $130069 \mathrm{~km}^{2}$. The state average annual rainfall is $945 \mathrm{~mm}$ (Agrawal, Yogesh Chandra 2012). 1 Mha area is irrigated by 60 reservoirs. Tank and the well irrigating area is $0.8 \mathrm{M}$. ha and $1.2 \mathrm{M}$ ha, respectively. The total number of well is $1.6 \mathrm{M}$. According to NITI; the total groundwater recharge is 2.24 MHM (NITI Aayog 2018). The total surface water availability is $2.50 \mathrm{MHM}$ and groundwater is 2.24 MHM (Himanshu Thakkar (2018). More than 90 percent of accessible water uses for irrigation. The water Demand is increasing for the growing population (Rathore and Singh 2011). Care should be taken to the agricultural water requirement for current and future needs (Srinivasan and Kulkarni 2014). Tamil Nadu's irrigation potential is 0.08 hectares, and India's irrigation is 0.17 hectares (Season and Crop Report 2017-18). Domestic and industrial demand is 15 percent of the total demand at the present level. And it would be increased to Twenty-five percent in the year 2025 AD.

Oveexploitation of groundwater, insufficient rainfall, and limited groundwater replenishment resulted in groundwater table decline in all parts of the Bhavani basin. Supply is fixed, it has to be

How to cite this article: Malaisamy, A. 2021. Water Supply and Demand for Different Sectors in Bhavani Basin. IJAEB, 14(2): 191-198.

Source of Support: None; Conflict of Interest: None 
shared by various users in an optimum way, and this has assumed very significance at present in the state (UN Water 2019). Water is demanded multiple uses like population, urbanization, and industry sectors. Hence, increasing demand from multiple uses leads to water transfers from irrigated agriculture. This water transfer is important issues in Tamil Nadu. Water transfer is more prevalent in the Bhavani Basin. In this basin, demand for water to agricultural, domestic, and industrial is very high, and the significances of water transfer are still thoroughly not studied.

\section{RESULTS AND DISCUSSION}

\section{Cropping Pattern in Agricultural Sector in Old Ayacut and New Ayacut}

Agricultural demand constitutes the significant sectoral demand in the basin. Two anicuts, namely Kodivery and Kalingarayan, and three canals, namely Arakankottai, Thadapalli, and Kalingarayan canals, are irrigating about 16,000 ha of land. Water is allowed for about $10-1 / 2$ months in the $1^{\text {st }}$ and $2^{\text {nd }}$ channels and 11 months in the $3^{\text {rd }}$ channel. Continuous supplies help raise a short-duration crop of paddy like IR-50, followed by mediumduration paddy. After the two paddy crops, the land is used to grow a green manure crop like sun hemp or fodder sorghum. The cropping patterns in the Lower Bhavani basin for the study area are given in Table 1.

Table 1: Cropping Pattern in Lower Bhavani Basin (Ayacut)

\begin{tabular}{llll}
\hline Sl. No Crop & Area (ha) & $\begin{array}{l}\text { Percentage to } \\
\text { Ayacut Area }\end{array}$ \\
\hline 1 & Paddy & 25188 & 24.79 \\
2 & Sugar cane & 6300 & 6.20 \\
3 & Banana & 933 & 0.92 \\
4 & Turmeric & 3331 & 3.28 \\
5 & Groundnut & 10304 & 10.14 \\
6 & Cotton & 3360 & 3.31 \\
7 & Pulse & 1702 & 1.68 \\
8 & Gingelly & 3000 & 2.95 \\
9 & Tapioca & 2205 & 2.17 \\
10 & Maize & 2496 & 2.46 \\
11 & Cholam & 3000 & 2.95 \\
12 & Coconut & 5150 & 5.07 \\
13 & Others & 34620 & 34.08 \\
\hline \multicolumn{6}{l}{ Gross } & Cropped Area & 101589 & 100.00 \\
\hline
\end{tabular}

Source: Joint Director of Agriculture Erode.
Based on the cropping pattern in the ayacut area of the basin, the relative percentage of area under significant crops in the ayacut was calculated and given in Table 2. It was seen from the information of the table that paddy occupied a major area $(24.13 \%)$ among significant crops and was followed by groundnut $(10.14 \%)$ and sugarcane $(6.20 \%)$ in the ayacut area. In total ayacut and non-ayacut area, paddy occupied $15.20 \%$ and followed by groundnut $10.61 \%$.

\section{Demand for Water in Agricultural Sector}

Water need was calculated based on crop water necessities. One could calculate the total irrigation water need of the agriculture sector by multiplying individual crop areas by the unit crop water requirement.

The demand for water in the agricultural sector at the gross water requirements level is given in Table 2. Water requirement calculated at 40 percent efficiency of water recommendation of each crop (Cauvery Basin Report by PWD, 2000). It was seen from the information table that the gross water requirement is about $3283.56 \mathrm{MCM}$.

\section{Supply-Demand Gap for Water in Agricultural Sector}

The details of total Supply and Demand for the water of the agricultural sector were calculated and presented in Table 3. It was seen from the details of the table that the total supply of surface water and ground water was 1516.12 MCM and 490.85 MCM, respectively. So, the total basin supply of water is 2006.97 MCM. Water demand was 3283.56 MCM in the basin. The quantity of Supply and Demand gap was 1487.49 MCM.

\section{Supply of and Demand for Water in Domestic Sector}

\section{Supply of Water}

The domestic requirements of the Bhavani river basin as also the adjacent Noyyal basin are met partly by surface water in the Bhavani river. The river provides water to several municipalities, town panchayats, and village panchayats for domestic consumption. The municipalities pump water for domestic requirements directly from the river. 
Table 2: Demand for Water in Agricultural Sector in Lower Bhavani Basin

\begin{tabular}{|c|c|c|c|c|c|c|c|}
\hline \multirow[b]{3}{*}{ Crops } & \multicolumn{7}{|c|}{ Lower Bhavani Basin } \\
\hline & \multirow{2}{*}{$\begin{array}{l}\text { Ayacut } \\
\text { Area* }\end{array}$} & \multirow{2}{*}{$\begin{array}{l}\text { Non Ayacut } \\
\text { Area* }\end{array}$} & \multirow{2}{*}{$\frac{\text { Water }}{\text { Ayacut }}$} & \multicolumn{3}{|c|}{ Requirement ${ }^{* * / h a}$ Water Demand ${ }^{* * *}(\mathrm{MCM})$} & \multirow{2}{*}{$\begin{array}{l}\text { Total Water } \\
\text { Requirement MCM } \\
\text { Column } 6+7\end{array}$} \\
\hline & & & & Non Arout & Ayacut & Non Ayacut & \\
\hline 1 & 2 & 3 & 4 & 5 & 6 & 7 & 8 \\
\hline Paddy & 25188 & 0 & 3000 & 0 & 755.64 & 0.00 & 755.64 \\
\hline Cumbu & 752 & 2603 & 1125 & 675 & 8.46 & 17.57 & 26.03 \\
\hline Maize & 2496 & 900 & 1500 & 900 & 37.44 & 8.10 & 45.54 \\
\hline Ragi & 7208 & 6883 & 1125 & 675 & 81.09 & 46.46 & 127.55 \\
\hline O.Small Millets & 2221 & 247 & 1125 & 1000 & 24.99 & 2.47 & 27.46 \\
\hline Red Gram & 255 & 1699 & 1250 & 750 & 3.19 & 12.74 & 15.93 \\
\hline B.Gram & 768 & 1423 & 1250 & 750 & 9.60 & 10.67 & 20.27 \\
\hline Gingelly & 3000 & 1018 & 625 & 375 & 18.75 & 3.82 & 22.57 \\
\hline Coconut & 5150 & 0 & 3750 & 3750 & 193.13 & 0.00 & 193.13 \\
\hline Caster & 347 & 1649 & 1000 & 600 & 3.47 & 9.89 & 13.36 \\
\hline Sunflower & 304 & 10 & 1125 & 675 & 3.42 & 0.07 & 3.49 \\
\hline Other oil seeds & 1620 & 470 & 1125 & 675 & 18.23 & 3.17 & 21.40 \\
\hline Cotton & 3360 & 2778 & 3250 & 1950 & 109.20 & 54.17 & 163.37 \\
\hline Sugercane & 6300 & 3128 & 6250 & 6250 & 393.75 & 195.50 & 589.25 \\
\hline Chillies & 617 & 0 & 1250 & 1125 & 7.71 & 0.00 & 7.71 \\
\hline Turmeric & 3331 & 2295 & 3750 & 3750 & 124.91 & 86.06 & 210.98 \\
\hline Arecanut & 571 & 0 & 1125 & 1000 & 6.42 & 0.00 & 6.42 \\
\hline
\end{tabular}

*Source: Joint Director of Agriculture Erode Note: ${ }^{* *}$ Water requirement at 40 per cent efficiency level. ${ }^{* * *}$ Effective Rainfall is not included.

Table 3: Supply-Demand Gap for Water in Agriculture

\begin{tabular}{lll}
\hline S1. No. & Particulars & MCM \\
\hline \multirow{4}{*}{1} & Supply: & 1516.12 \\
\cline { 2 - 3 } & Surface water & 490.85 \\
& Groundwater* & 2006.97 \\
\hline 2 & Total & 3283.56 \\
\hline 3 & Demand & -1276.599 \\
\hline
\end{tabular}

Source: * Calculated based on figures furnished by Central Ground Water Board.

The annual drawl from the river for the existing schemes and the schemes proposed in the future by the TWAD Board is of the order of 174 MCM. There are two water supply circles for household water requirements in Lower Bhavani Basin i.e. (1) Coimbatore circle and (2) Erode Circle; The details of the various schemes and their water supply are given in Table 4 and 5 .
The table indicates that nine schemes are running to provide drinking water supply to Coimbatore Circle. The total drawl from the Bhavaniriver for this Circle is 378.50 million liter per day (0.38 MCM) and a yearly 138.5 MCM. Among the nine schemes, five schemes running to give 335.86 million liter per day $(0.34 \mathrm{MCM})$ and yearly (122.58 MCM) of water to Noyyal Basin. There are 32 schemes running to 
Table 4: Drinking Water Supply Schemes in Coimbatore Circle

\begin{tabular}{lll}
\hline S1. No. & Scheme & $\begin{array}{l}\text { Quantity of drawl (millions of } \\
\text { liter per day ) }\end{array}$ \\
\hline 1 & Coimbatore corporation 20 town panchayats and 523 rural habitations & 131.25 \\
2 & Tiruppur municipality and 412 wayside habitations & 82.49 \\
3 & Karamadai T.P.I & 2.95 \\
4 & Thekkampatty CWSS & 0.72 \\
5 & Siruvani WSS & 101.4 \\
6 & Mettupalayam municipality & 20.94 \\
7 & Sirumugai & 3.64 \\
8 & CWSS to Annur - Avanashi & 15.11 \\
9 & CWSS to Koundampalayam and Vadavalli T.PTS & 20.00 \\
\hline Sub Total - 1 & 378.50 \\
\hline
\end{tabular}

Source: Government of Tamil Nadu Water Supply and Drainage Board, Erode .mld: million liters per day.

Table 5: Drinking Water Supply Schemes in Erode Circle

\begin{tabular}{|c|c|c|c|}
\hline Sl. No. & Scheme & Source & Quantity drawl (mld) \\
\hline 1 & WSIS to Sathyamangalam Municipality & Thalakarai & 20.40 \\
\hline 2 & WSS to Gobichettipalayam Municipality & Sengalakarai & 9.50 \\
\hline 3 & WSS to Bhavani Sagar & Bhavani Sagar Canal & 0.80 \\
\hline 4 & $\begin{array}{l}\text { WSS to Kothamangalam and four other village } \\
\text { panchayats in Bhavani \& Sathy Union }\end{array}$ & Kothamangalam & 2.86 \\
\hline 5 & WSS to Kembanaickanpalayam RTP & Periyakoduveri & 0.88 \\
\hline 6 & $\begin{array}{l}\text { CWSS to Kasipalayam and } 12 \text { other habitation in T.N } \\
\text { Palayam }\end{array}$ & Makkinam Kompai & 1.07 \\
\hline 7. & $\begin{array}{l}\text { CWSS to Periyapuliyur and ten other habitations in } \\
\text { Bhavani Union }\end{array}$ & Siraimeetanpalayan & 0.30 \\
\hline 8 & $\begin{array}{l}\text { CWSS to Kadayampatti and } 4 \text { other habitations in } \\
\text { Bhavani Union }\end{array}$ & Thalavaipettai & 0.48 \\
\hline 9 & WSS to Jambei RTP in Bhavani Union & Thalavaipettai & 1.59 \\
\hline 10 & $\begin{array}{l}\text { CWSS to Vellalapalayam, Vellankoil and } 54 \text { other } \\
\text { Habitations in Gobi Union }\end{array}$ & Nanjayagoun-danpalayam & 1.66 \\
\hline 11 & $\begin{array}{l}\text { CWSS to Doddampalayam and } 116 \text { wayside } \\
\text { Habitations in Erode district }\end{array}$ & Bagadu Durai & 3.23 \\
\hline 12 & $\begin{array}{l}\text { CWSS to Periya Kodiveri and seven other village } \\
\text { panchayats in T.N. Palayam Union }\end{array}$ & Kodiveri & 4.10 \\
\hline 13 & CWSS to Kugalur and Athani T.P. & Kuppandampalayam & 2.88 \\
\hline 14 & WSS to Nambiyur and five other Village Panchayat & Makkinam Kompai & 1.75 \\
\hline 15 & $\begin{array}{l}\text { CWSS to Mahalipudur and } 7 \text { other habitations in } \\
\text { Nambiyur in Sathy union }\end{array}$ & Makkinam Kompai & 1.06 \\
\hline 16 & $\begin{array}{l}\text { CWSS to Goundampalayam and seven other } \\
\text { habitations in Gobi and Bhavani Unions }\end{array}$ & Perunthalaiyur & 1.10 \\
\hline 17 & $\begin{array}{l}\text { CWSS to Olagadam RTP and } 4 \text { VPRTs in Ammapet } \\
\text { and Bhavani Union }\end{array}$ & Thalavaipettai & 1.16 \\
\hline 18 & WSS to Appakudal RTP in Erode district & Kotham Poondi & 1.00 \\
\hline 19 & $\begin{array}{l}\text { CWSS to Kavunapadi, P. Mettupalayam and } \\
\text { Salangapalayam town panchayat }\end{array}$ & Perunthalaiyur & 2.21 \\
\hline
\end{tabular}




\begin{tabular}{|c|c|c|c|}
\hline 20 & $\begin{array}{l}\text { CWSS to Pudukothukadu and } 4 \text { other habitations in } \\
\text { Sathy and Bhavanisagar }\end{array}$ & Ariyappampalayam & 0.72 \\
\hline 21 & CWSS to Kalingayam, and Siruvallur RTP & Sengalakarai & 5.18 \\
\hline 22 & $\begin{array}{l}\text { CWSS to Vemmandampalayam and seven other } \\
\text { village PTS in Nambiyur Union }\end{array}$ & Pudukothukadu & 2.35 \\
\hline 23 & $\begin{array}{l}\text { WSS to Ariyapampalayam RTP and Konamoor } \\
\text { village panchayat }\end{array}$ & Pudukothukadu & 2.95 \\
\hline 24 & $\begin{array}{l}\text { CWSS to Nallampatty, Pethampalayam, Kanjikoil and } \\
\text { Pallapalayam RTPs }\end{array}$ & Siraimeetan -Palayam & 6.65 \\
\hline 25 & $\begin{array}{l}\text { CWSS to Elathur, Nambiyur RTP and Kosanam, } \\
\text { Thalkuni VPTs in Erode }\end{array}$ & Arasur & 8.633 \\
\hline 26 & $\begin{array}{l}\text { CWSS to Nagalur and two other panchayats in } \\
\text { Anthiyur Union }\end{array}$ & Near Athani & 1.89 \\
\hline 27 & CWSS to 17 habitation s in Chinnapuliyur & Vairamangalam & 0.44 \\
\hline 28 & WSS to Punjaipuliyampatti UTP & Bagadu Durai & 2.94 \\
\hline 29 & WSIS to Anthiyur UTP & Athani & 2.62 \\
\hline 30 & CWSS to Kavundapadi, V.P. & Kuttipalayam & 3.30 \\
\hline 31 & CWSS to Moongilpatti, Kilvani, Vempanthi & Moongilapatti & 0.80 \\
\hline 32 & WSIS to Siruvalur VP & Kavundapadi & 0.50 \\
\hline \multicolumn{3}{|c|}{ Sub Total-II } & 97.13 \\
\hline \multicolumn{3}{|c|}{ Total } & $475.63 \mathrm{mld}$ \\
\hline & & & $174 \mathrm{MCM} /$ year \\
\hline
\end{tabular}

Source: Tamil Nadu Water Supply and Drainage (TWAD) Board, Erode 2017-18.

Note: CWSS: Combined Water Supply Scheme; WSS: Water Supply Scheme; WSIS: Water Supply Improvement Scheme.

give drinking water to Erode Circle. The total drawl from the Bhavani river in this Circle is $97.126 \mathrm{mld}$ (0.09 MCM) and yearly 35.45 MCM. Hence, the total drinking water drawl from the Bhavani river is both for Coimbatore and Erode circles, which is $475.626 \mathrm{mld}(0.48 \mathrm{MCM})$, and yearly it is 173.60 million cubic meters

\section{Demand for Water in Domestic Sector}

The requirement of water in the domestic sector has been estimated based on per day water recommended level by the TWAD board. The total water Demand of the domestic sector was estimated by multiplying the population of the basin by the per day water allocation norms of the TWAD board. Tamil Nadu Water Supply and Drainage Board recommendation level per day for rural areas was 90 liters per capita per day, and urban, municipalities, corporation areas were 110 liters per capita per day. The water requirement for the domestic sector is given in Table 6. It was seen from the details of the table that the need is about $93.68 \mathrm{MCM}$ per year (256.66 MLD), and supply is 51.01per year (139.76
MLD) in the basin. The gap is $42.66 \mathrm{MCM} /$ year (116.9 MLD)

\section{Demand for Water and Supply in Noyyal Basin from Bhavani River}

The details of the Supply and Demand for water in the Noyyal basin to be met out from the Bhavaniriver are given in Table 7. From the table, it is found that 335.86 MLD (133.25 MCM yearly) of water supplied from the Bhavani river to the Noyyaland 253.56 MLD (92.54 MCM) demanded in the Noyyal basin. The excess water supply was 82.3 MLD (30.03 MCM).

\section{Industrial Water Supply and Demand}

The Water Resource Organization (WRO) has permitted 20 industries to draw a total quantity of 39.152 MCM (1,383 Mcft)/year. Out of 20 industries, seven industries sectors are on the upstream side of Bhavanisagar, and the remaining 13 industries sectors are downstream. 
Table 6: Domestic Demand for and Supply of water in Lower Bhavani Basin for 2018-19

\begin{tabular}{lllllll}
\hline S1. No. & Population & Old Ayacut & New Ayacut & $\begin{array}{l}\text { Total } \\
\text { Population }\end{array}$ & $\begin{array}{l}\text { Recommend water supply** } \\
\text { Liters per capita per day }\end{array}$ & $\begin{array}{l}\text { Total million } \\
\text { liters per day }\end{array}$ \\
\hline I & Demand: & & & & & \\
1 & Rural & 1053090 & 972084 & 2025174 & 90 & 182.26 \\
2 & Urban & 351738 & 324682 & 676420 & 110 & 74.40 \\
\hline & Total & 1404829 & 1296765 & 2701594 & & 256.66 \\
\hline II & Actual drawl: & & & & 42.64 \\
A & Coimbatore Circle & & 139.76 & 97.12 \\
B & Erode Circle & & -116.9 & \\
\hline Total & & & $42.66 \mathrm{MCM} /$ year & \\
\hline III & Demand-Supply Gap & & & & \\
\hline
\end{tabular}

Source: *Population statistics 2011, Assistant Director of Statistics Erode and Coimbatore; ${ }^{* *}$ Tamil Nadu Water Supply and Drainage Board, Government of Tamil Nadu.

Table 7: Domestic Demand for Water in Noyyal Basin and Supply from Bhavani River for 2018-19

\begin{tabular}{|c|c|c|c|c|}
\hline S1. No & Population & Total Population & Recommend water supply** (LPCD) & Total MLD \\
\hline I & \multicolumn{4}{|l|}{ Demand: } \\
\hline 1 & Rural & 1085682 & 90 & 97.71 \\
\hline \multirow[t]{2}{*}{2} & Urban Population & 1416822 & 110 & 139.66 \\
\hline & Total & 2502504 & & 253.56 \\
\hline II & \multicolumn{2}{|c|}{ Supply Coimbatore Circle } & & 335.86 \\
\hline III & \multicolumn{2}{|c|}{ Demand-Supply Gap } & $\begin{array}{l}+82.3 \\
30.03 \mathrm{MCM} / \text { year }\end{array}$ & \\
\hline
\end{tabular}

Source: * Population Statistics 2011, Assistant Director of Statistics, Coimbatore; ** Tamil Nadu Water Supply and Drainage Board recommendation level; Note: LPCD: Liters per capita per day and MLD: Million liters per day.

Table 8: Industries Permitted by the Government to Draw Water from Bhavani River

\begin{tabular}{lll}
\hline Sl. No. & Name of Industry & Quantity (M $\mathbf{M}^{3}$ year) \\
\hline 1 & M/s Encee Aromatics, Mettupalayam & 30,405 \\
2 & M/s Indo Swiss Synthetic Gem Manufacturing CO, MTP & $5,67,341$ \\
3 & M/s Nanjiah Lingammal Polytechnic, Mettupalayam & 16,593 \\
4 & M/s Sudarasan Paper Mills Mothepalayam, Sirumugai & $5,97,213$ \\
5 & M/s Sri Vishnedevi Mills Pvt. Ltd., Jedayampalayam & $2,19,000$ \\
6 & M/s Siruvani Textile (P) Ltd., Jedayampalayam & 41,482 \\
7 & M/s Micro Tex India Limited Tiruppur & $1,82,500$ \\
8 & M/s South India Viscose Ltd., Sirumugai & $2,15,55,060$ \\
9 & M/s T T Maps Pungar Bhavani Sagar, Sathy Taluk & $16,60,750$ \\
10 & M/s Sam Turbo Industry Bhavani Sagar & $7,30,000$ \\
11 & M/s Sri Karthikega Paper and Board Limited, Rajanagar & $1,83,000$ \\
12 & M/s Talent Paper Board (P) Ltd., Rajanagar & $14,60,000$ \\
13 & M/s Bannariamman Sugars Ltd., Sathy Taluk & $16,32,645$ \\
14 & M/s Bannariamman Sugars (Granite Division) Sathy Taluk & $7,87,991,54,750$ \\
15 & M/s Bannariamman Educational Trust, Alathukombai & 54,750 \\
16 & M/s KPR Mills (P) Ltd., Indiampalayam, Sathy Taluk & 54,750 \\
17 & Sri Bhavani Textiles (P) Ltd., Akkaraikodivery, Erode & $1,36,875$ \\
18 & M/s Sathy Sugars Ltd., Appakudal, Bhavani Taluk & $39,81,420$ \\
19 & Tamil Nadu Newsprint \& Paper Ltd., Kagithapuram, Karur & 88,635 \\
20 & M/s Coimbatore Alcohol \& Chemicals Ltd., Bhavani & $51,76,153$ \\
\hline & Total & $3,91,52,563$ \\
& & (or) 39.15MCM \\
\hline
\end{tabular}


Three Sectors Demand and Supply of Water in Bhavani Basin

The three sectors, water Demand, and Supply, are presented in Table 9. It was seen from the details of the table that in all the sectors, water demand is more than the Supply excluding in inter-basin need of domestic water supply (82.3 MCM).

\section{Projection of water Demand in Domestic and Industrial sector}

With projections of the population to be served by the basin water, the actual requirement for the future population was worked out (the population needs 90 liters/person/day in rural areas and 110 liters/person/day in urban areas). Thus demand for water for domestic sector requirement for any time period in MCM (for the year 2011 and 2031) was calculated by the following method and presented in Table 10.

$$
\begin{aligned}
& r_{i}=\left[\left(p_{2001} / \mathrm{p}_{1991}\right)^{1 / 10}\right]-1 \\
& r_{i}=\left[(2025174 / 1746993)^{\wedge} 0.1\right]-1 \\
& r_{i}=0.01 \\
& p_{r 2011}=p_{r 2001}\left(1+r_{i}\right)^{10} \\
& p_{r 2011}=17.47 \times 1.01^{\wedge} 10=20.25 \text { lakhs; }
\end{aligned}
$$

Where, $p_{r}=$ rural population.

It was seen from the information of the table that domestic sector demand for water based on existing supply norms projected as varied from about 66.53 MCM in 2001 to about 81.04 MCM in 2031 in rural areas. Similarly, in urban areas with the present supply norms, the projections varied from about 27.16

\begin{tabular}{|c|c|c|c|c|c|}
\hline S1. No. & Sectors & & Demand & Supply & Gap \\
\hline 1 & Agriculture (MCM) & & 3283.56 & 2006.97 & -1276.59 \\
\hline \multirow[t]{5}{*}{2} & Domestic & & & & \\
\hline & (a) Intra basin & (MLD) & 256.66 & 139.76 & -116.90 \\
\hline & & $(\mathrm{MCM})$ & 93.68 & 51.01 & -42.67 \\
\hline & (b) Interbasin & (MLD) & 253.56 & 335.86 & +82.3 \\
\hline & & $(\mathrm{MCM})$ & 92.54 & 133.25 & +30.03 \\
\hline 3 & Industry (MCM) & & 39.15 & 39.15 & 0.00 \\
\hline
\end{tabular}
MCM in 2001 to approximately 33.08 MCM in 2031. The projected total demand thus ranges from 93.69 MCM in 2001 to about 114.12 MCM in 2031.

Table 9: Different Sectors Water Demand and Supply in Bhavani Basin

Table 10: Projection of Demand for Water in Domestic Sector

\begin{tabular}{lllllllll}
\hline \multirow{2}{*}{ S1 .No } & Population & \multicolumn{3}{c}{ Population (lakhs) } & Growth & $\begin{array}{l}\text { 2001 Water } \\
\text { requirement / } \\
\text { RCM }\end{array}$ & $\begin{array}{l}\text { 2011 Water } \\
\text { requirement / } \\
\text { MCM }\end{array}$ & $\begin{array}{l}\text { 2031 Water } \\
\text { requirement / } \\
\text { MCM }\end{array}$ \\
\cline { 3 - 8 } & $\mathbf{2 0 0 1}$ & $\mathbf{2 0 1 1}$ & $\mathbf{2 0 3 1}$ & & $\mathbf{M C M}$ & 73.42 & 81.04 \\
\hline 1 & Rural & 17.47 & 20.25 & 22.35 & 10.1 & 66.53 & 29.97 & 33.08 \\
2 & Urban & 5.73 & 6.76 & 7.47 & 10.2 & 27.16 & 103.40 & 114.12 \\
\hline
\end{tabular}

Table 11: Compound Growth Rate of each Category of Industries

\begin{tabular}{lllllll}
\hline \multirow{2}{*}{ S1. No. } & \multirow{2}{*}{ Category of Industry } & \multirow{2}{*}{ GCR } & \multirow{2}{*}{ t value } & \multicolumn{3}{c}{ Demand for water (MCM) } \\
\cline { 5 - 7 } & & & Present & $\mathbf{2 0 1 1}$ & $\mathbf{2 0 3 1}$ \\
\hline 1 & Sugar $(\mathrm{N}=2)$ & 13.30 & $1.73(0.445)$ & 5.61 & 6.35 & 7.20 \\
2 & Paper $(\mathrm{N}=6)$ & 9.23 & $14.57(0.006)$ & 4.72 & 5.15 & 5.66 \\
3 & Rayon $(\mathrm{N}=1)$ & 12.48 & $2.821(0.041)$ & 21.56 & 24.25 & 27.16 \\
4 & Distillery $(\mathrm{N}=2)$ & 13.71 & $5.57(0.023)$ & 5.18 & 5.89 & 6.69 \\
\hline
\end{tabular}


Considering industrial demand for water, the existing level as estimated based on quantities drawn by the licensed industries is about 39.15 MCM representing about 1.92 percent of the basin resources. The Water Resource Organization (WRO) has permitted 20 industries. The compound growth rate was worked out for industries sectors and is given in Table 11. It was seen from the table that rayon industries water requirement is high (24.25 MCM) in next decade followed by sugar (6.35 MCM), distillery (5.89 MCM) and Paper (5.15 $\mathrm{MCM})$.

The other minor industry water requirement for the last ten years was not available. Take the average compound growth rate of significant industries and assume this compound growth rate $(12.18 \%)$ for minor industries sectors. So, the total industrial water requirement increases from the present demands of 39.15 MCM 2001-01 to 47.37 MCM in 2031. It is important to analyze why this gap between demand for and water Supply occurs among different sectors.

\section{CONCLUSION}

The urban demand will be expanding due to government priority for drinking water; it is necessary to protect the future needs. Projections of the population made at existing norms of 90 liters/ person/day in rural areas and 110 liters/ person/ day in urban areas. Domestic sector demand for water based on existing supply norms has varied from 66.53 MCM in 2001 to $81.04 \mathrm{MCM}$ in 2021 in rural areas. Similarly, in urban areas with the present supply norms, the projections changed from about 27.16 MCM in 2001 to about $33.08 \mathrm{MCM}$ in 2025. The projected total demand thus ranges from 93.69 MCM in 2001 to about 114.12 MCM in 2021. The whole industrial water requirement increase from present needs of 39.15 MCM 2001-01 to 47.37 MCM in 2021.

\section{REFERENCES}

Agrawal, Y.C. 2012. "Rehabilitation of Water Resources," Paper presented at India Water Week 10-14 April, 2012Water, Energy, and Food Security: Call for Solutions, New Delhi.

Cullet, P. 2012. "Is Water Policy the New Water Law? Rethinking the Place of Law in Water Sector Reforms," IDS Bulletin, 43(2): 69-78.

NITI Aayog, 2018. “Composite Water: Management Index: A Tool for Water Management," Ministry of Water Resources, Ministry of Drinking Water and Sanitation, Ministry of Rural Development, Government of India, http://niti.gov.in/writereaddata/files/document_publicati on/2 0 18-05 -18-Water-Index-Report_vS8- compressed. pdf. 28.09.2019

Palanisami, K. 2013. "Final Draft Report of the FPARP," International Water Management Institute, Hyderabad.

Rathore and Singh, N. 2011. "A Historical Perspective of the Development of Rain Water Harvesting Techniques in the Mewar Region, Udaipur, Rajasthan, India," Int. J. Water Res. Arid Env., 1(4): 285-94.

Season and Crop Report, 2017-18, Government of Tamil Nadu.

Srinivasan, Veena and Kulkarni, Seema. 2014. “Examining the Emerging Role of Groundwater in Water Inequity in India," Water Int., 39(2): 172-86.

Thakkar, Himanshu. 2018. "AIBP: Just a Pack of Unverifiable Claims or Worse," South Asia Network on Dams, Rivers \& People, HTTPS:// sandrp.in/2018/03/29/aibp-just-a-packof-unverifiable-claims-or-worse/Last access - 28.09.2019

UN Water, 2019. Leaving No One Behind, The United Nations World Development Report, UNESCO.

Ministry of Water Resources, 2018 estimate report, Government of India. 